Pesquisa Florestal Brasileira
Brazilian Journal of Forestry Research
https://www.embrapa.br/pfb

\title{
Nota Científica \\ Sciarid fungus-gnats as nuisance factor in Pinus timber yards
}

\author{
Guilherme Schnell e Schühli ${ }^{1}$ Susete do Rocio Chiarello Penteado1, Wilson Reis Filho ${ }^{1}$, Dalton Souza Amorim² \\ ${ }^{1}$ Embrapa Florestas, Estrada da Ribeira, km 111, CP 319, Colombo, PR, Brasil \\ ${ }^{2}$ Universidade de São Paulo, Faculdade de Filosofia Ciências e Letras de Ribeirão Preto, Departamento de Biologia, Av. Bandeirantes, 3900, CEP 14.040-901, \\ Ribeirão Preto, SP, Brasil
}

\author{
"Autor correspondente: \\ guilherme.schuhli@embrapa.br \\ Index terms: \\ Bradysia \\ Entomology \\ Urban infestation \\ Wood stocking \\ Fungus-gnats \\ Termos para indexação: \\ Bradysia \\ Entomologia \\ Infestação urbana \\ Estocagem de madeira \\ Fungus-gnats
}

Histórico do artigo:

Recebido em 13/06/2014

Aprovado em 01/12/2014

Publicado em 31/12/2014

doi: 10.4336/2014.pfb.34.80.732

\begin{abstract}
Some Sciaridae species are considered as cosmopolitan pests in greenhouses and mushrooms farms. The potential harm of these insects involves plant tissue damage and transmission of pathogens to the seedlings. Recently, large sciarid masses were found infesting wood log stocking of processing industries and turned to be a severe nuisance factor and a public health issue. The Sciarid specimens from infested areas were identified belonging to the genus Bradysia Winnertz, 1867. These species certainly do not correspond to pests, but to species that are possibly associated to microenvironments generated by the fungi on the wood bark.
\end{abstract}

\section{Fungus-gnats (Sciaridae) como um fator de importuno em pátios de toras de pinus}

\begin{abstract}
Resumo - Algumas espécies de Sciaridae são consideradas pragas cosmopolitas em estufas, criações de cogumelos e até mesmo em vasos de plantas. A ameaça potencial destes insetos envolve o dano de tecido vegetal e a transmissão de patógenos às mudas. Recentemente, grandes massas de sciarídeos foram encontradas infestando o estoque de toras de indústrias madeireiras e se tornaram um fator de incômodo e preocupação de saúde pública. Os espécimes foram identificados como pertencendo ao gênero Bradysia Winnertz, 1867. Estas espécies certamente não constituem uma praga, mas possivelmente estão associadas a microambientes gerados pelos fungos sob a casca das toras.
\end{abstract}

The fungus-gnats comprise a large group of flies including the families Sciaridae, Mycetophilidae, Keroplatidae, and some other smaller families. These families are quite scarcely known in some regions, especially in the Neotropics. Few of their representatives are known as cosmopolitan pests in greenhouses, mushrooms farms and even flower boxes (Mohrig \& Menzel, 2009). The potential harm of these insects involves plant tissue damage and transmission of several pathogens to the seedlings (as the genera Pythium, Botrytis, Verticillium, Fusarium, Thielaviopsis, Cylindrocladium e Sclerotinia - Leite et al., 2007;
Mead \& Fasulo, 2001; Hurley et al., 2010). In spite of these reports, actions for sciarid control are still scarce in many countries. In Brazil, we also have quite good number of reports records of severe damages to commercial greenhouses and, specially, to mushroom farms (Amorim, 1992; Menzel et al., 2003; Leite et al., 2007; Guimarães et al., 2008).

Recently, sciarids have been reported as a concern from an entirely different perspective. Large masses of adults were found to infest wood stocking of processing industries (Schuhli et al., 2013). These infestations turned to be a severe nuisance factor and a public health issue. 
The nearby inhabitants complained over huge masses of these flies carried by the wind to their houses. The producers personally reported that sciarid flies were already known to develop on pine logs in the harvest areas. Consequently their existence in log yards was noted before as a normal occurrence. Apparently, the recent rise of the sciarid population in timber yards coincide with changes in harvesting practices and productive methods (as example, bark removal was once processed in field; currently the log is transported and piled with bark).

In this note we report the infestation of two pine log yards. We identified the involved insect to the species level. This note reports the Sciarid as a nuisance factor outside the context of greenhouses and mushroom farms. To a certain extent, it constitutes an important record to position the family not only as an agricultural harm but also to public health. Until now, the nuisance to humans is the only harm scientifically recorded and there is no reason to worries other than controlling the sciarid population. Our note also calls the scientific community attention to the fact that taxonomic studies and management and control practices protocols are urgent demands especially for the Neotropical region.

The first infested log yard area was in the county of Araucaria, metropolitan region of Curitiba, Paraná State, Brazil. This timber yard with circa 4 ha, asphalt paved. The second infested area was located in Piên, also in Paraná State, with three unpaved industrial yards with circa each. In both industries the logs with different cutting age were gathered from different geographical origins comprising mainly Paraná, Santa Catarina and Rio Grande do Sul.

The immature were found in large numbers in the space between bark and wood. Fungi or the abundant sap and resin are probable food source. The log piles offer ideal temperature and humidity conditions to development of many nematocerous Diptera, where Sciaroidea compose the vast majority. In both sites, log piles reaches circa five meters high with two log measures $(2.10 \mathrm{~m}$ or $4.20 \mathrm{~m}$ ) in lines that vary from $30 \mathrm{~m}$ to $70 \mathrm{~m}$ long. The piles are maintained as log stock to prevent lacking of wood during rainy seasons. Their permanence time in stock vary from the immediate processing to more than half year. The involved companies reported that the infestation possibly occur during all year.

Both companies also reported that occurrence of the sciaroidea flies in logs does not interfere with desired wood properties or qualities. The only problem frequently reported is the nuisance caused by the files to nearby houses and factory workers. Large masses of flies infest the facilities and are dispersed by wind to the neighborhoods.

We carried on manual (entomological net and aspirator) and trap aided collection on both sites. Ethanolic fluorescent white light trap were used. Immature insects were killed in warm water and preserved in ethanol $98^{\circ} \mathrm{GL}$. Adult insects were killed directly in $70{ }^{\circ} \mathrm{GL}$ Ethanol and subsequently either clarified in potassium hydroxide (Steffan, 1983) or directly and mounted in permanent slides for identification. Taxonomic identification was proceed at Embrapa Florestas Entomology Laboratory and confirmed at Diptera's Morphology and Evolution Laboratory (Universidade de São Paulo). We based our identification in Mohrig \& Menzel (2009) key and in a genus redescription (Menzel et al., 2003). Besides the occurrence of mostly Bradysia sciarid species, we also often collected representatives of other families, as chironomids, mycetophilids, cecids, and scatopsids.

To illustrate the severity of the infestation we presented here one typical capture in yellow adhesive trap exposed for 20 hours (Figure 1) in the wood piles. The intensity of infestation on the referred collection day was considered as "normal" by the company's representatives. During high levels of infestation sampling time has to be largely reduced otherwise counting would not be possible. The capture intensity suggests the importance and urgency of sciarid control in log yards.

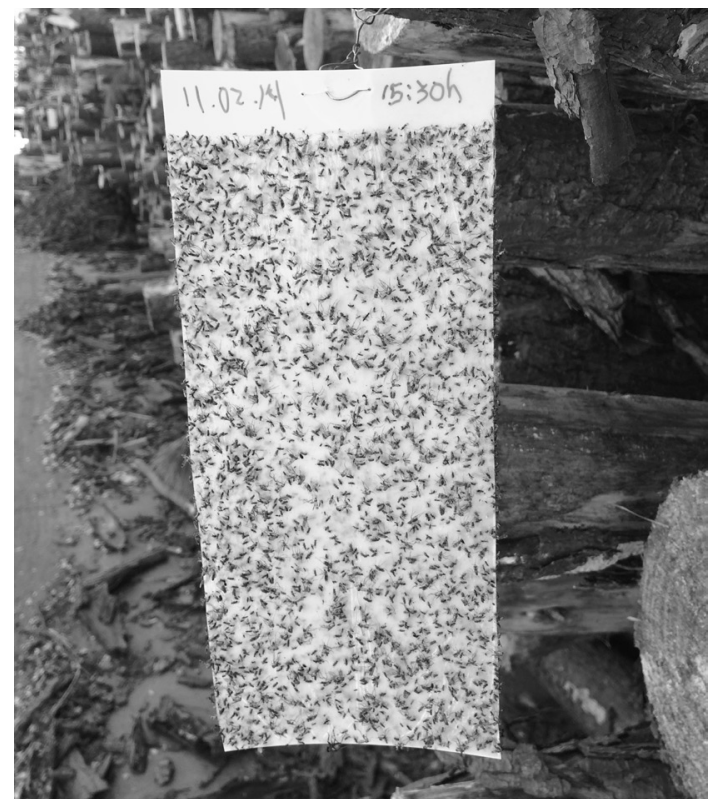

Figura 1. Yellow adhesive trap $(11 \mathrm{x} 25 \mathrm{~cm}$, kept at $1,50 \mathrm{~m}$ from ground level) after 20 hours of exposition. 
Sciarid specimens were all identified belonging to the genus Bradysia Winnertz, 1867. A large collection of samples was gathered in ethanol. It is worth of note, however, that the specimens belong to ten different species of Bradysia, as well as of females that possibly belong to additional species of the genus. This material is being studied to proceed with eventual new descriptions based on morphology (including DNA barcoding). Actions to record density of sciarid infestation are being taken by the commercial wood companies (represented by APRE Associação Paranaense de Empresas de Base Florestal) and Embrapa Florestas. Chemical and biologic control and lifecycle studies are undergoing. This record also clarifies some issues concerning the biology of many sciarids. The species collected certainly do not correspond to pests, but to species that are possibly associated to microenvironments generated by the fungi on the wood bark.

\section{References}

AMORIM, D. S. A catalogue of the family Sciaridae (Diptera) in the Americas South of the United States. Revista Brasileira de Entomologia, São Paulo, v. 36, n. 1, p. 55-77, 1992.

GUimarẽes, J. A.; CAstro, A. C. R.; MESQUitA, A. L.; BRAGA SOBRINHO, R.; AZEVEDO, F. R. Manual de reconhecimento e controle das principais pragas do Antúrio. Fortaleza: Embrapa Agroindústria Tropical, 2008. 20 p. (Embrapa Agroindústria Tropical. Documentos, 114).

HURLEY, B. P.; SLIPPERS, B.; WINGFIELD, B. D.; GOVENDER, P.; SMITH, J. E.; WINGFIELD, M. J. Genetic diversity of Bradysia difformis (Sciaridae: Diptera) populations reflects movement of an invasive insect between forestry nurseries. Biological Invasions, v. 12, p. 729-733, 2010.

LEITE, L. G.; AMBRÓS, C. M.; TAVARES, F. M.; BÚSSOLA, R. A.; AMORIM, D. S.; HARAKAVA, R. Virulência de nematóides entomopatogênicos (Nematoda: Rhabditida) contra larvas da mosca-dos-fungos Bradysia mabiusi (Lane, 1959) e persistência de Heterorhabditis indica Poinar et al. 1992 em substratos orgânicos, dentro de casa de vegetação. Arquivos do Instituto Biológico, São Paulo, v. 74, n. 4, p. 337-342, 2007.

MEAD, F. W.; FASULO, T. R. Darkwinged Fungus Gnats, Bradysia spp. (Insecta: Diptera: Sciaridae). Gainesville, University of Florida, 2001. 4 p. (Florida Department of Agriculture and Consumer Services. Division of Plant Industry Entomology Circular, 186).

MENZEL, F.; SMITH, J. E.; COLAUTO, N. B. Bradysia difformis Frey and Bradysia ocellaris (Comstock): two additional neotropical species of black fungus gnats (Diptera: Sciaridae) of economic importance: a redescription and review. Annals of the Entomological Society of America, College Park, v. 96, p. 448-457, 2003. DOI:10.1603/ 0013-8746(2003)096[0448:BDFABO]2.0.CO;2
MOHRIG, W.; MENZEL, F. Sciaridae (Black Fungus Gnats). In: BROWN, B. V.; BORKENT, A.; CUMMING, J. M.; WOOD, D. M.; WOODLEY, N. E.; ZUMBADO, M. A. (Ed.). Manual of Central American Diptera. Ottawa: NRC Research Press, 2009, p. 279-292.

SCHUHLI, G. S.; PENTEADO, S. R. C.; REIS FILHO, W.; NICKELE, M. A. Medidas contingenciais para o controle de sciarídeos (moscas-dos-cogumelos) em pátios de toras de pínus. Colombo: Embrapa Florestas, 2013. 5 p. (Embrapa Florestas. Comunicado técnico, 315).

STEFFAN, W. A. Preparation of slide mounts of Sciaridae (Diptera). International Journal of Entomology, Honolulu, v. 25, n. 2-3, p. 231-232, 1983. 